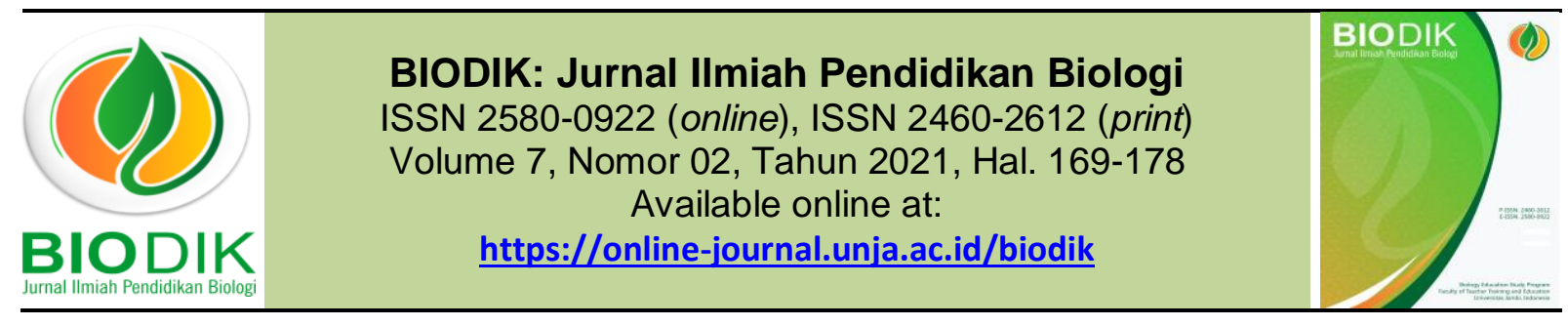

Research Article

OPEN ACCESS

\title{
Analisis Kendala Praktikum Biologi di Sekolah Menengah Atas
}

\section{(Obstacles Analysis of Biology Laboratory Practice of High School)}

\author{
Nur Rahmah, Iswadi*, Asiah, Hasanuddin, Devi Syafrianti \\ Program Studi Pendidikan Biologi, Fakultas Keguruan dan IImu Pendidikan, Universitas Syiah Kuala \\ Jl. Tgk. Hasan Krueng Kalee, Darussalam, Banda Aceh \\ ${ }^{*}$ Corresponding Author: iswadi_yusuf@unsyiah.ac.id
}

\begin{tabular}{|c|c|}
\hline Informasi Artikel & ABSTRACT \\
\hline $\begin{array}{l}\text { Submit: } 01-02-2021 \\
\text { Diterima: } 20-03-2021 \\
\text { Dipublikasikan: } 01-06-2021\end{array}$ & $\begin{array}{l}\text { This study aims to determine the completeness of laboratory facilities and } \\
\text { infrastructures, the implementation of the laboratorial practice, to measure the causal } \\
\text { factors of laboratorial practice to run, and to be alert of laboratory infrastructure } \\
\text { completeness and the implementation of the biology laboratorial practice. The type of } \\
\text { research methods applied in this research is the quantified qualitative method. Data } \\
\text { were collected by observation and questionnaires. The sample in this study were } 11 \\
\text { high schools in Banda Aceh, with respondents } 11 \text { biology teachers who are } \\
\text { responsible for teaching class XI and } 99 \text { students of class XI IPA. The data were } \\
\text { analyzed using the proportion formula and the product moment answer formula. The } \\
\text { study resulted in the findings that: 1) the proportion of completeness of facilities and } \\
\text { infrastructure was } 66.77 \% \text { (good). 2) the proportion of laboratorial ptactice } \\
\text { implementation was } 62.81 \% \text { (sufficiently implemented). 3) factors of laboratorial } \\
\text { procurement, including, inadequate support, inadequate materials, insufficient time } \\
\text { allocation, lack of readiness of laboratory assistants in preparing tools and materials, } \\
\text { absence of laboratory assistants in several sample schools, and some biology I } \\
\text { laboratory assistants in The sample school had never been trained to guide students } \\
\text { or to use laboratory equipment. 4) the correlation between the laboratory facilities } \\
\text { completeness and infrastructure with laboratorial practice implementation was } 0.27 \\
\text { (low). }\end{array}$ \\
\hline & Keywords: Biology, laboratorial, obstacle, practice \\
\hline Penerbit & ABSTRAK \\
\hline $\begin{array}{l}\text { Program Studi Pendidikan Biologi } \\
\text { FKIP Universitas Jambi, } \\
\text { Jambi- Indonesia }\end{array}$ & $\begin{array}{l}\text { Penelitian ini bertujuan untuk mengetahui kriteria kelengkapan sarana dan prasarana } \\
\text { laboratorium, kriteria keterlaksanaan praktikum, mengumpulkan faktor kendala yang } \\
\text { menyebabkan kurang berjalannya praktikum, dan untuk mengetahui korelasi antara } \\
\text { kelengkapan sarana prasarana laboratorium dengan keterlaksanaan praktikum } \\
\text { biologi. Jenis metode penelitian yang diterapkan yaitu metode kualitatif yang di } \\
\text { kuantitatifkan. Pengumpulan data dilakukan dengan cara observasi dan angket. } \\
\text { Sampel dalam penelitian ini adalah } 11 \text { SMA di Kota Banda Aceh, dengan responden } \\
11 \text { guru biologi yang mengajar kelas XI dan } 99 \text { peserta didik kelas XI IPA. Data } \\
\text { dianalisis dengan menggunakan rumus persentase dan rumus korelasi Product } \\
\text { moment. Hasil penelitian diketahui bahwa: } 1 \text { ) persentase kelengkapan sarana dan } \\
\text { prasarana laboratorium sebesar } 66,77 \% \text { (baik). 2) persentase keterlaksanaan } \\
\text { praktikum sebesar } 62,81 \% \text { (cukup terlaksana). 3) faktor kendala pelaksanaan } \\
\text { praktikum diantaranya, fasilitas pendukung yang tidak memadai, minimnya } \\
\text { kelengkapan bahan praktikum, alokasi waktu untuk praktikum tidak mencukupi, }\end{array}$ \\
\hline
\end{tabular}


kurangnya kesiapan laboran dalam mempersiapkan alat dan bahan praktikum, tidak adanya laboran di beberapa sekolah sampel, dan sebagian guru biologi/laboran di sekolah sampel belum pernah mengikuti pelatihan mengenai praktikum atau penggunaan alat laboratorium. 4) korelasi antara kelengkapan sarana dan prasarana laboratorium dengan keterlaksanaan praktikum sebesar 0,27 (rendah).

Katakunci: Biologi, laboratorium, kendala, praktikum

This BIODIK : Jurnal IImiah Pendidikan Biologi is licensed under a CC BY-NC-SA (Creative Commons Attribution-ShareAlike 4.0 International License)

\section{PENDAHULUAN}

Wawasan sains diperoleh dan dikembangkan melalui sebuah rangkaian penelitian yang dilakukan oleh sainstis dalam mencari jawaban dari beberapa pertanyaan seperti, "apa?", "mengapa?", dan "bagaimana?" dari gejala alam serta penerapannya dalam teknologi dan kehidupan sehari-hari. Pendidikan sains juga menegaskan pada pemberian pengalaman langsung untuk mengembangkan kompetensi agar peserta didik mampu dalam menjelajahi dan memahami alam sekitar secara ilmiah (Rahayu dkk, 2012).

Pembelajaran biologi di sekolah dapat menerapkan metode ilmiah dengan membiasakan peserta didik melakukan kerja ilmiah. Pembelajaran biologi juga dapat memotivasi peserta didik untuk melakukan kerja ilmiah. Salah satu kegiatan yang menerapkan metode ilmiah dalam pembelajaran biologi adalah pelaksanaan praktikum (Rahayu dkk, 2012; Atnur dkk, 2015). Pembelajaran biologi tidak dapat dipisahkan dengan kegiatan praktikum, hal ini disebabkan karena banyaknya konsep abstrak dalam materi biologi yang harus dimengerti oleh peserta didik. Peran praktikum disini dapat membuat konsep abstrak menjadi konsep yang lebih mudah ditangkap oleh peserta didik (Dewi dkk, 2014). Dalam pembelajaran biologi salah satu kegiatan yang menerapkan metode ilmiah yaitu dengan melaksanakan kegiatan praktikum (Atnur dkk, 2015). Melalui kegiatan praktikum yang optimal maka diharapkan dapat mencapai suatu tujuan pembelajarannya dengan baik (Lafenasti, 2018).

Laboratorium berperan sebagai tempat untuk peserta didik melatih keterampilan melalui berbagai macam kegiatan seperti eksperimen maupun aktivitas ilmiah lainnya. Praktikum sudah menjadi komponen penting dalam pembelajaran biologi. Namun kenyataannya pelaksanaan praktikum di sekolah masih belum berjalan secara baik (Atnur dkk, 2015).

Kendala dalam kegiatan praktikum biologi di semester ganjil kelas XI di SMAN Kabupaten Karo diantaranya alokasi waktu yang tergolong kurang baik $46 \%$, peralatan laboratorium $63 \%$ dan perlengkapan laboratorium 56\% yang kurang baik (Rezeqi, 2012). Keterlaksanaan praktikum biologi di SMA Negeri Kota Jambi tergolong kedalam kriteria baik dengan persentase sebesar 65,38\%, namun masih terdapat hambatan yang dialami guru dalam kegiatan praktikum tersebut. Kendala yang dihadapi oleh pendidik adalah keberadaan laboratorium itu sendiri yang tidak digunakan sebagai tempat praktikum biologi, melainkan dijadikan sebagai ruang kelas untuk belajar (Hamidah, 2014). Permasalahan dalam kegiatan praktikum biologi di SMAN 16 Medan diantaranya ketersediaan waktu 
untuk kegiatan praktikum tidak mencukupi, penuntun praktikum yang tidak tersedia, tidak ada laboran dan bahan di laboratorium tidak memadai (Siburian dkk 2017).

Hasil wawancara dengan beberapa guru biologi dan hasil observasi yang telah dilakukan di Sekolah Menengah Atas Kota Banda Aceh, diketahui bahwa sebagian sekolah dalam pembelajaran biologi kelas XI untuk pelaksanaan praktikum masih jarang dilaksanakan. Hal ini dikarenakan alokasi waktu yang masih kurang, kurangnya sarana dan prasarana penunjang praktikum di laboratorium dan kurangnya pemanfaatan laboratorium di sekolah yang sudah memiliki fasilitas laboratorium yang memadai.

Keterlaksanaan praktikum perlu dilengkapi dengan kebutuhan laboratorium yang mendukung.. Pemahaman guru terhadap keterlaksanaan praktikum di laboratorium juga menjadi salah satu faktor pendukung atau penghambat terlaksananya praktikum. Apabila kegiatan praktikum tidak terlaksana dengan optimal, maka pencapaian pembelajaran aspek psikomotor tidak tercapai dengan baik( Oktavia, 2012; Sukmawati, 2013; Indrawan, 2015; Rahman dkk, 2015; Nazila dkk, 2017). Laboratorium tidak berfungsi jika tidak dilengkapi dengan kebutuhan untuk praktikum. Tidak layaknya sarana dan prasarana merupakan salah satu kendala praktikum. Laboratorium membutuhkan tenaga khusus/laboran yang bertugas menyiapkan perlengkapan yang dibutuhkan untuk praktikum dan mengelola laboratorium (Endela dkk, 2019).

Kurang berjalannya praktikum disekolah merupakan suatu hal yang dapat mengkhawatirkan dalam proses pembelajaran biologi, dan akan berdampak pada pemahaman peserta didik terhadap pembelajaran biologi. Tindakan yang dilakukan dengan mengumpulkan masalah/ kendala penyebab tidak terlaksananya kegiatan praktikum secara optimal dan mencari solusi alternatif penyelesaian masalah praktikum biologi di SMA Kota Banda Aceh. Harapannya penelitian ini dapat memberikan solusi kepada sekolah untuk kendala yang selama ini di hadapi, agar kedepannya pelaksanaan praktikum biologi dapat berjalan dengan baik.

\section{METODE PENELITIAN}

Pendekatan penelitian yaitu pendekatan kualitatif yang dikuantitatif. Jenis penelitian yang digunakan berupa penelitian deskriptif. Populasi dalam penelitian ini adalah SMA yang ada di Kota Banda Aceh. Sampel penelitian ini adalah 11 SMA Kota Banda Aceh, responden terdiri 11 guru mata pelajaran biologi yang mengajar kelas XI dan 99 peserta didik kelas XI IPA.

Instrumen yang digunakan dalam penelitian ini berupa angket tertutup dengan skala Guttman dan daftar checklist. Teknik pengumpulan data dilakukan dengan angket dan observasi. Untuk pengumpulan data kelengkapan sarana dan prasarana laboratorium dilakukan observasi dengan menggunakan lembar check-list berdasarkan standar Permendiknas Tahun 2007. Untuk pengumpulan data keterlaksanaan praktikum dilakukan dengan menggunakan angket berdasarkan silabus biologi kelas XI. Untuk pengumpulan data tanggapan guru dan tanggapan peserta didik mengenai kendala pelaksanaan praktikum biologi dilakukan dengan menggunakan angket yang diadopsi dari jurnal Rahman (2015). Analisis data dilakukan menggunakan persentase dan korelasi Product moment. Selanjutnya data disajikan dalam bentuk tabel atau grafik. 


\section{HASIL DAN PEMBAHASAN}

\section{Faktor Kendala Praktikum Biologi}

Berikut adalah data tanggapan peserta didik dan guru mengenai kendala praktikum biologi kelas XI di SMA Kota Banda Aceh.

Tabel 1. Tanggapan Peserta Didik Mengenai Kendala Praktikum Biologi kelas XI di SMA Kota Banda Aceh

\begin{tabular}{|c|c|c|c|c|}
\hline NO & Pernyataan & $\begin{array}{c}\text { Pilihan } \\
\text { Jawaban }\end{array}$ & $\mathbf{F}$ & $\%$ \\
\hline \multirow{2}{*}{1} & \multirow{2}{*}{$\begin{array}{l}\text { Sering mengikuti kegiatan praktikum di } \\
\text { laboratorium? }\end{array}$} & $\mathrm{Ya}$ & 48 & 48,48 \\
\hline & & Tidak & 51 & 51,52 \\
\hline \multirow{2}{*}{2} & \multirow{2}{*}{$\begin{array}{l}\text { Pernah mengalami "tidak ada bahan" } \\
\text { dalam kegiatan praktikum ? }\end{array}$} & $\mathrm{Ya}$ & 59 & 59,60 \\
\hline & & Tidak & 40 & 40,40 \\
\hline \multirow{2}{*}{3} & \multirow{2}{*}{$\begin{array}{l}\text { Waktu yang dialokasikan untuk praktikum } \\
\text { mencukupi? }\end{array}$} & $\mathrm{Ya}$ & 44 & 44,44 \\
\hline & & Tidak & 55 & 55,56 \\
\hline \multirow{2}{*}{4} & \multirow{2}{*}{$\begin{array}{l}\text { Guru anda sering menggunakan metode } \\
\text { praktikum dalam mengajar? }\end{array}$} & $\mathrm{Ya}$ & 45 & 45,45 \\
\hline & & Tidak & 54 & 54,55 \\
\hline
\end{tabular}

Tabel 1 merupakan hasil angket tanggapan peserta didik mengenai kendala praktikum, diketahui bahwa yang menjadi faktor kendala praktikum diantaranya, peserta didik tidak sering mengikuti praktikum, hal ini disebabkan karena guru tidak sering menggunakan metode praktikum dalam pembelajaran biologi. Faktor selanjutnya yaitu tidak tersedianya bahan praktikum yang memadai, sehingga praktikum terhambat dikarenakan sering habis bahan untuk praktikum. Faktor selanjutnya yaitu alokasi waktu untuk praktikum tidak mencukupi, hal ini terjadi karena banyaknya hari libur yang ada pada semester genap tersebut. Sehingga pada saat praktikum sering mengalami kekurangan waktu. (Nur, 2015) juga menyampaikan bahwa alokasi waktu yang telah dirancang sedemikianrupa berdasarkan kalender pendidikan sering mengalami perubahan seperti perubahan ujian nasional, perubahan waktu libur dan berbagai kegiatan lain yang serba tiba-tiba, selain itu alokasi waktu yang ditetapakan dalam pelajaran biologi tidak seimbang dengan KD yang harus diajarkan. Hal inilah sehingga praktikum tidak dapat terlaksana dengan semestinya.

Tabel 2. Tanggapan Guru Mengenai Kendala Praktikum Biologi Kelas XI di SMA Kota Banda Aceh

\begin{tabular}{|c|c|c|c|c|}
\hline No & Pernyataan & $\begin{array}{l}\text { Pilihan } \\
\text { Jawaban }\end{array}$ & $\mathbf{F}$ & $\%$ \\
\hline \multirow{2}{*}{1} & \multirow{2}{*}{ Fasilitas pendukung tidak memadai } & Ya & 6 & 54,55 \\
\hline & & Tidak & 5 & 45,45 \\
\hline \multirow{2}{*}{2} & \multirow{2}{*}{ Alokasi waktu praktikum tidak mencukupi } & Ya & 6 & 54,55 \\
\hline & & Tidak & 5 & 45,45 \\
\hline \multirow{2}{*}{3} & \multirow{2}{*}{$\begin{array}{l}\text { Kurangnya kesiapan laboran dalam } \\
\text { mempersiapkan kebutuhan praktikum }\end{array}$} & $\mathrm{Ya}$ & 9 & 81,82 \\
\hline & & Tidak & 2 & 18,18 \\
\hline \multirow{2}{*}{4} & \multirow{2}{*}{ Tidak adanya laboran disekolah } & $\mathrm{Ya}$ & 6 & 54,55 \\
\hline & & Tidak & 5 & 45,45 \\
\hline
\end{tabular}


Tabel 2 merupakan hasil angket tanggapan guru mengenai kendala praktikum, diketahui bahwa kendala praktikum diantaranya, fasilitas pendukung di laboratorium tidak memadai. Mauliza dan Nurhafidhah (2019) menyatakan bahwa penyebab fasilitas pendukung tidak memadai dikarenakan kurangnya alokasi dana yang tersedia untuk laboratorium, sehingga untuk mencukupi kebutuhan fasilitas laboratorium sekolah harus memikirkan anggaran yang ada untuk dapat memenuhi keperluan fasilitas laboratorium. Kendala berikutnya adalah alokasi waktu praktikum tidak mencukupi. Waktu untuk praktikum harus diatur semaksimal mungkin karena pada pelaksanaan praktikum memiliki kegiatan yang banyak dan persiapan yang cukup (Rahman dkk, 2006; Rezeqi, 2012).

Kendala berikutnya yaitu kurangnya kesiapan laboran dalam menyiapkan kebutuhan praktikum. (Mauliza dan Nurhafidhah, 2019) menyampaikan bahwa kurangnya kesiapan laboran ini dikarenakan kurangnya kegiatan pelatihan yang didapatkan oleh laboran. Faktor berikutnya yaitu tidak adanya laboran, sehingga guru merasa kewalahan dalam mempersiapkan praktikum. Hal ini sejalan dengan pendapat (Arikunto, 2008) jika yang menjadi laboran adalah guru yang juga mengajar dikelas maka praktikum akan sulit dilaksanakan. Praktikum membutuhkan dukungan dari berbagai pihak, seperti tenaga laboran yang bertugas membantu guru dalam pelaksanaan praktikum di laboratorium.

\section{Solusi Untuk Mengatasi Kendala Praktikum Biologi}

Solusi untuk mengatasi kendala praktikum yang didapatkan dari hasil angket peserta didik dan guru. Kendala pertama yang didapatkan adalah alokasi waktu yang tidak mencukupi. Hal ini seharusnya dapat diatasi jika pendidik mengatur alokasi waktu untuk tahap-tahap pembelajaran dengan matang. Masalah ini juga dapat diatasi bila guru dan laboran mempersiapkan keperluan praktikum sebelum jam pelajaran tersebut berlangsung, sehingga dapat menghemat waktu yang digunakan selama praktikum (Sardiman, 2015)). Guru juga dapat memberikan waktu tambahan sebelum jam pulang sekolah apabila waktu untuk melaksanakan praktikum tidak mencukupi (Siburian dkk, 2017).

Kendala selanjutnya adalah fasilitas pendukung tidak memadai. (Yaman, 2016) menyampaikan bahwa kendala tersebut dapat dikomunasikan pada kepala sekolah dan komite sekolah terkait mengenai permasalahan sarana dan prasarana laboratorium, untuk dilakukan penyusunan anggaran dan mengajukan permohonan bantuan dana pengembangan laboratorium kepada pihak yang terkait. (Sukmawati, 2013) juga menyampaikan bahwa pihak sekolah melalui instansi terkait dapat memenuhi kebutuhan laboratorium sekolah, baik dari segi ketersediaan alat dan bahan keperluan praktikum serta tenaga laboran, dan melaksanakan pelatihan peningkatan profesional guru khususnya pengelolaan laboratorium.

Kendala selanjutnya yaitu kurangnya kesiapan laboran mempersiapkan kebutuhan praktikum dan sebagian guru belum pernah mengikuti pelatihan yang berkaitan dengan penggunaan alat-alat laboratorium. Solusi untuk mengatasi kendala ini yaitu dengan pemberian pelatihan teknik laboratorium kepada pendidikan dan tenaga laboran (Rahman dkk, 2015). (Hofstein dk, 2004) juga menyampaikan bahwa pendidik membutuhkan wawasan, skills dan sumber daya serta mampu meningkatkan kemampuan investigasi dan refleksi. 


\section{Kelengkapan Sarana dan Prasarana Laboratorium}

Hasil penlitian untuk kelenkapan sarana dan prasarana laboratorium biologi menunjukkan skor persentase yang berbeda, data disajikan pada Gambar 1.

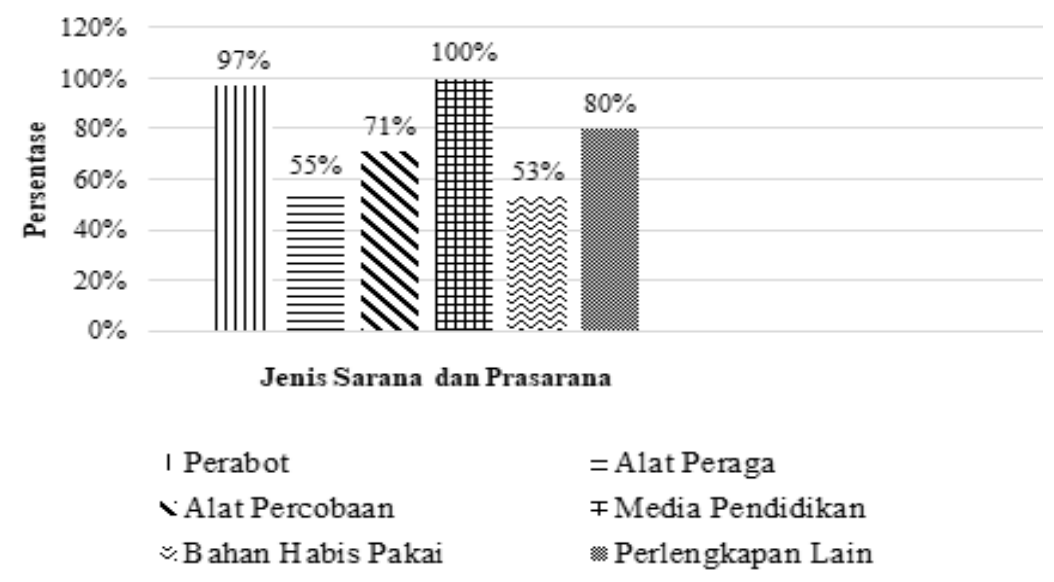

Gambar 1. Persentase Kelengkapan Sarana dan Prasarana Laboratorium Biologi

Data di dapatkan dari hasil pengamatan langsung dan terdiri dari perabot, alat peraga, alat pecobaan, media pendidikan, bahan habis pakai dan perlengkapan lain.

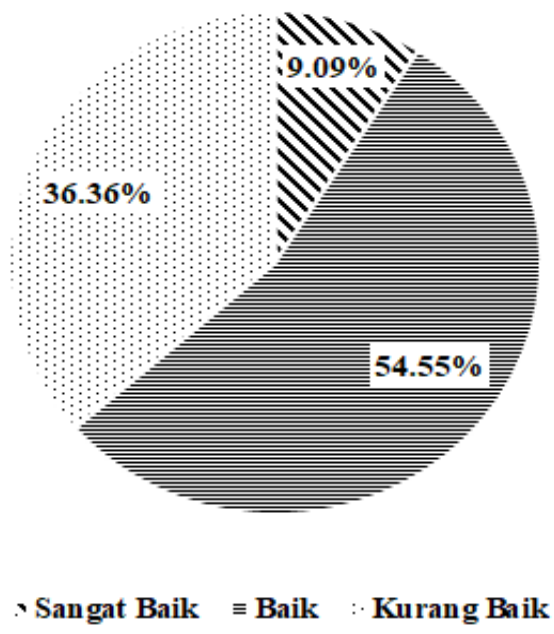

Gambar 2. Persentase Kriteria Kelengkapan Sarana dan Prasarana Laboratorium Biologi

Berdasarkan Gambar 2 diketahui bahwa dari 11 sampel sekolah dikota Banda Aceh dan tergolong kedalam kriteria sangat baik sebanyak 1 sekolah $(9,09 \%)$, kiteria baik sebanyak 6 sekolah $(54,55 \%)$ dan kriteria kurang baik sebanyak 4 sekolah $(36,36 \%)$.

Hasil perhitungan rata-rata nilai persentase untuk kelengkpan kebutuhan laboratorium di Sekolah Menengah Atas Kota Banda aceh adalah 66,77\% dan tergolong kedalam kriteria baik. Oktavia: Rezeqi, (2012: 2012) menyatakan bahwa laboratorium yang baik yaitu laboratorium yang difasilitasi dengan berbagai fasilitas baik dari segi ruang dan kelengkapan serta kondisi sarana dan prasarana baik.

Berdasarkan hasil penelitian dan perhitungan persentase diketahui bahwa untuk kelengkpan sarana dan prasarana laboratorium biologi di Sekolah Menengah Atas Kota Banda Aceh, dari segi

\section{Rahmah, dkk}


kelengkapan perabot nilai persentase menunjukkan angka $97,40 \%$ dan tergolong kedalam kriteria baik. Untuk alat peraga nilai persentase menunjukkan angka 55,27\% dan tergolong kedalam kriteria kurang baik. Kelengkapan alat percobaan nilai persentase menunjukkan angka $70,96 \%$ dan tergolong kedalam kriteria baik. Untuk kelengkapan media pendidikan nilai persentase menunjukkan angka 100\%, setiap sekolah sampel sudah tersedia papan tulis didalam laboratorium. Untuk kelengkapan bahan habis nilai persentase menunjukkan angka 53,15\% dan tegolong kedalam kriteria kurang baik.

Berdasarkan standar Permendiknas Nomor 24 Tahun 2007, bahan habis pakai (bahan praktikum) dapat diartikan sebagai bahan yang penggunaanya habis dalam waktu yang relative singkat. Apabila habis, maka sekolah harus memesan kembali. Untuk kelengkapan perlengkapan lain nilai persentase menunjukkan angka $80 \%$ dan tergolong kedalam kriteria baik. (Tarmizi, 2009) menyampaikan bahwa akan ada kemungkinan terjadinya kebakaran di laboratorium. Pelarut organik yang sifatnya mudah menguap, peralatan elektronik juga memungkinkan dapat terbakar akibat korsleting, maka itu alat pemadam perlu tersedia di laboratorium. (Daryanto, 2018) juga menyampaikan bahwa disamping pentingnya keberadaan alat pemadam kebakaran, diperlukan juga peralatan P3K. Meskipun P3K ini bersifat sesaat, namun diharapkan dapat mencegah bertambah parahnya luka dan dapat meminimalisir penderitaan pada korban di laboratorium.

\section{Keterlaksanaan Praktikum Biologi}

Berikut adalah data keterlaksanan praktikum biologi kelas XI di SMA Kota Banda Aceh dan diperoleh dari hasil angket. Data dapat disajikan pada Gambar 3 dan Gambar 4.

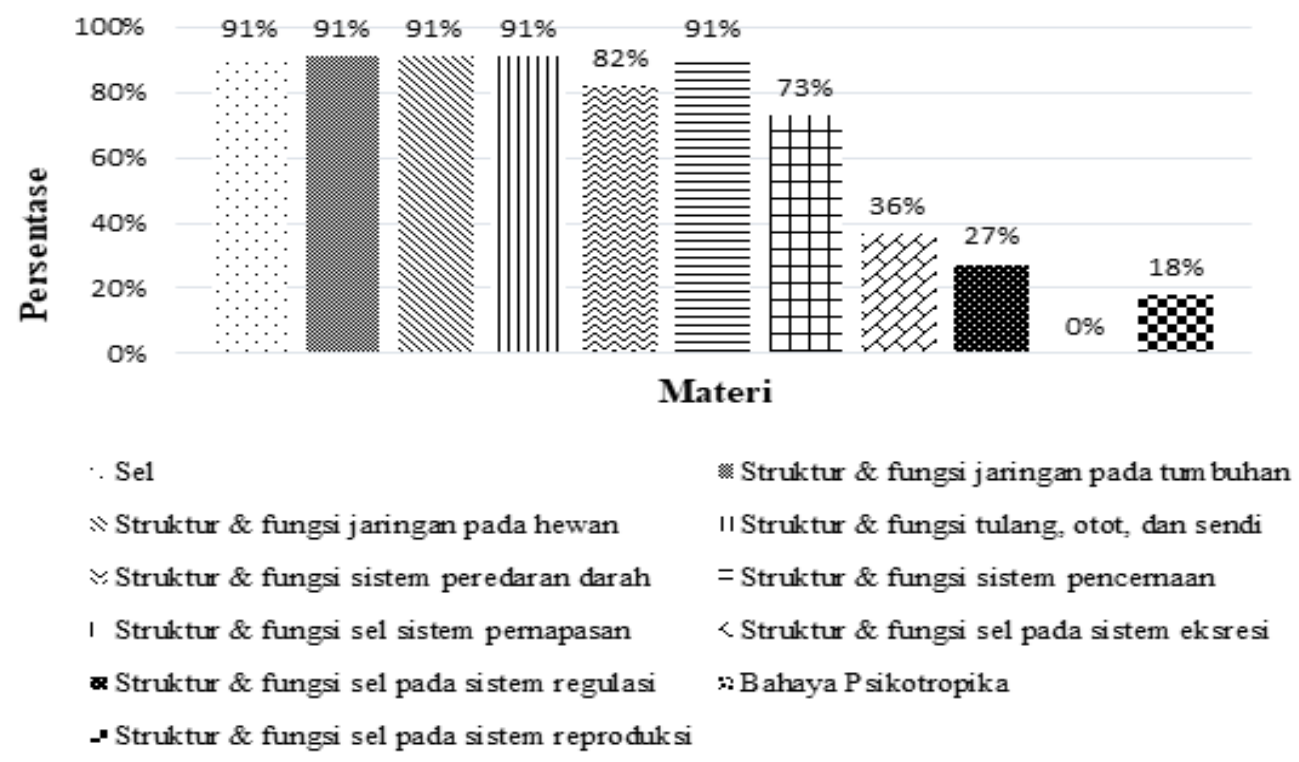

Gambar 3. Persentase Keterlaksanaan Praktikum Biologi Kelas XI

Berdasarkan Gambar 3 diatas, hasil penelitian menunjukkan bahwa masing-masing materi mendapatkan skor persentase yang berbeda-beda. Data keterlaksanaan praktikum biologi kelas XI menunjukkan bahwa dari 11 materi yang tersedia pada mata pelajaran biologi kelas XI diketahui bahwa pada materi bahaya psikotropika mendapatkan persentase yang sangat rendah yaitu $0 \%$, artinya pada materi tersebut tidak terlaksananya praktikum. 


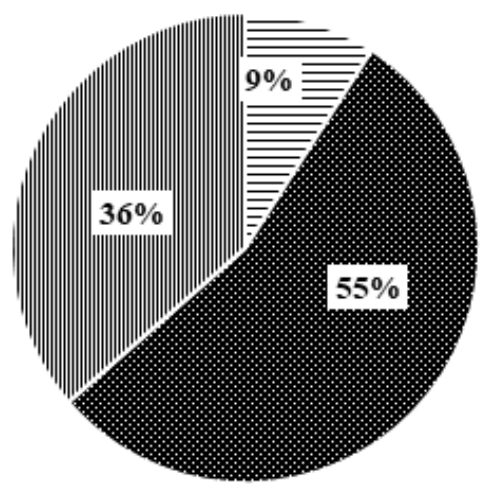

- Sangat Terlaksana 9 Cukup Terlaksana "Sangat Kurang Terlaksana

Gambar 4. Persentase Kriteria Keterlaksanaan Praktikum Biologi Kelas XI

Berdasarkan Gambar 4 dapat diketahui bahwa keterlaksanaan praktikum biologi kelas XI dari 11 sekolah sampel yang ada dikota Banda Aceh didapatkan data yang tergolong kedalam kriteria sangat terlaksana sebanyak 1 sekolah (9\%), kiteria cukup terlaksana sebanyak 6 sekolah (55\%), dan kriteria sangat kurang terlaksana sebanyak 4 sekolah (36\%).Berdasarkan hasil angket yang diberikan kepada guru dapat diketahui bahwa keterlaksanaan praktikum biologi di kelas XI SMA Kota Banda Aceh dapat dikategorikan kedalam kriteria cukup terlaksana dengan nilai persentase sebesar $62,81 \%$. Berdasarkan hasil wawancara dengan pendidik di sekolah sampel, bahwa ketidakterlaksaan prakticum tersebut dikarenakan adanya beberapa kendala yang dihadapi. Kendala tersebut diantaranya tidak tersedianya alat peraga untuk praktikum, tenaga pengajar yang kurang, tidak adanya laboran dibeberapa sekolah, alokasi waktu yang tidak mencukupi, laboratorium biologi masih disatukan dengan laboratorium kimia atau fisika, dan alokasi waktu yang telah dibuat terkadang sering mengalami perubahan dikarenakan banyaknya hari libur yang ada pada semester genap tersebut.

\section{Korelasi Antara Kelengkapan Sarana dan Prasarana Laboratorium Biologi dengan Keterlaksanaan Praktikum Biologi}

Berdasarkan hasil analisis menggunakan rumus korelasi product moment, untuk kelengkapan srana dan prasarna lab dengan keterlaksanaan praktikum bilogi di SMA Kota Banda Aceh, dari 11 sekolah sampel diperoleh nilai $r$ yaitu 0,27 dan tergolong kedalam kriteria rendah. Artinya bahwa hubungan antara kelengkapan sarana dan prasarana labratorium dengan keterlaksanaan praktikum biologi di SMA Kota Banda Aceh tidak mempunyai hubungan yang erat.

Hal ini menunjukkan bahwa minimnya pemanfaatan labortorium di yang telah mempunyai fasilitas yang memadai, sehingga praktikum yang semestinya dapat terlaksana dengan optimal menjadi tidak sepenuhnya dapat terlaksana karena kurangnya pemanfaatan laboratorium di SMA Kota Banda Aceh. Hal ini sejalan dengan pendapat (Junaidi dkk, 2018) dalam jurnalnya yang menyatakan bahwa meskipun keberadaan sarana dan prasarana laboratorium sudah baik akan tetapi belum menjamin untuk praktikum dapat terlaksana dengan baik. Hal ini juga diduga disebabkan oleh keterbatasan kemampuan sumber daya manusia serta manajemen laboratorium yang ada disekolah kurang optimal.

\section{Rahmah, dkk}




\section{SIMPULAN}

Berdasarkan hasil penelitian dan analisis data dapat disimpulkan bahwa persentase kelengkapan sarana dan prasarana laboratorium sebesar $66,77 \%$ (baik). Persentase keterlaksanaan praktikum sebesar $62,81 \%$ (cukup terlaksana). Faktor kendala pelaksanaan praktikum diantaranya, fasilitas pendukung yang tidak memadai, minimnya kelengkapan bahan praktikum, alokasi waktu untuk praktikum tidak mencukupi, kurangnya kesiapan laboran dalam mempersiapkan alat dan bahan praktikum, tidak adanya laboran di beberapa sekolah sampel, dan sebagian guru biologi/laboran di sekolah sampel belum pernah mengikuti pelatihan mengenai praktikum atau penggunaan alat laboratorium. Korelasi antara kelengkapan sarana dan prasarana laboratorium dengan keterlaksanaan praktikum sebesar 0,27 (rendah).

\section{RUJUKAN}

Arikunto, S. (2008) Prosedur Penelitian: Suatu Pendekatan Praktik. Jakarta: Rineka Cipta.

Atnur, W. N., Lufri, L. \& Sumarmin, R. (2015). Analisis Pelaksanaan Praktikum IPA Biologi Kelas VIII Semester 1 di SMP Negeri se-Kecamatan Lubuk Begalung Tahun Pelajaran 2014/2015. Jurnal Pendidikan Biologi Kolaboratif, 2(2): 1-21.

Daryanto (2018). Manajemen Laboratorium Sekolah. Yogyakarta: Penerbit Gava Media.

Dewi, I. S., Sunariyati, S. \& Neneng, L. (2014). Analisis kendala pelaksanaan praktikum biologi di SMA Negeri se-kota Palangka Raya. Edu Sains: Jurnal Pendidikan Sains dan Matematika, 2(1): 13-26.

Endela, E. Z. et al. (2019) 'Student S ' Perceptions Of Practicum Activities In The Biology Laboratory SMA Negeri 2 Painan', Bioeducation Journal, 4(1): 126-134.

Hamidah, A. (2014). Persepsi siswa tentang kegiatan praktikum biologi di laboratorium SMA Negeri SeKota Jambi. Sainmatika: Jurnal Sains dan Matematika Universitas Jambi. Jambi University, 8(1): 49-59.

Hofstein, A. \& Lunetta, V. N. (2004). The Laboratory in Science Education: Foundations for the twentyfirst century., Science education. Wiley Online Library, 88(1): 28-54.

Indrawan, I. (2015). Pengantar manajemen sarana dan prasarana sekolah. Yogyakarta: Deepublish.

Junaidi, E., Hadisaputra, S. \& Al Idrus, S. W. (2018). Kajian Pelaksanaan Praktikum Kimia Di Sekolah Menengah Atas Di Kabupaten Lombok Barat Indonesia', Jurnal Pijar Mipa, 13(1): 24-31.

Lafenasti, F. (2018). Analisis Hambatan Pelaksanaan Praktikum Fisika Di SMA Negeri 5 Kota Jambi. Repository Universitas Jambi. 15 Februari 2018

Mauliza, M. \& Nurhafidhah, N. (2019). Kesiapan dan Pemanfaatan Laboratorium Kimia Pada Pelaksanaan Praktikum Di Sma N 1 Langsa. Prosiding Seminar Nasional Politeknik Negeri Lhokseumawe,2(1): 36-41.

Nazila, N. \& Nevrita, B. I. (2017). Analisis Pelaksanaan Praktikum Pada Pembelajaran Biologi Kelas X MAN Tanjungpinang Tahun Ajaran 2016/2017. Artikel. 1-6

Nur, S. (2015). Studi tentang Faktor Penghambat yang Dihadapi Guru Biologi dalam Menyusun Rancangan Pelaksanaan Pembelajaran Kurikulum Tingkat Satuan Pendidikan di SMP se Kecamatan Bastem Kabupaten Luwu, Jurnal bionature, 16(2): 110-116.

Oktavia, I.P., Wachju S. \& Sulifah Aprilya Hariani, H. (2012). Hubungan Tingkat Intensitas dan Kualitas Kegiatan Praktikum di Laboratorium Biologi dengan Hasil Belajar Siswa SMA Negeri di Kabupaten Situbondo. Artikel Ilmiah Mahasiswa, 1-5.

Peraturan Menteri Pendidikan Nasional Nomor 24. (2007). Standar Sarana dan Prasarana untuk Sekolah Dasar/ Madrasah Ibtidaiyah (SD/MI), Sekolah Menengah Pertama/ Madrasah Tsanawiyah (SMP/MTS), dan Sekolah Menengah Atas/Madrasah Aliyah (SMA/MA). Jakarta: Departemen Pendidikan Nasional.

Purwanto, N. (2010). Prinsip-prinsip dan Teknik Evaluasi Pengajaran. Bandung: Rosda Karya.

Rahayu, P., Mulyani, S. and Miswadi, S. S. (2012). Pengembangan pembelajaran IPA terpadu dengan 
menggunakan model pembelajaran problem base melalui lesson study. Jurnal Pendidikan IPA Indonesia, 1(1): 63-70.

Rahman, D., Adlim, A. and Mustanir, M. (2015). Analisis kendala dan alternatif solusi terhadap pelaksanaanpraktikum kimia pada slta negeri kabupaten aceh besar. Jurnal Pendidikan Sains Indonesia (Indonesian Journal of Science Education), 3(2): 1-13.

Rahman, T. et al. (2006). Profil Kemampuan Generik Perencanaan Percobaan Calon Guru Hasil Pembelajaran Berbasis Kemampuan Generik pada Praktikum Fisiologi Tumbuhan. Jurnal Pendidikan dan Budaya, 4(1): 72-87.

Rezeqi, S. (2012). Analisis Pelaksanaan Praktikum Biologi Dan Permasalahannya Di Sma Negeri Sekabupaten Karo. Jurnal Tabularasa. PPS UNIMED, 9(01): 17-32.

Sarapina, N. (2015). Permasalahan Pelaksanaan Praktikum Kimia dan Alternatif Penyelesaiannya di MAN 3 Banda Aceh. Skipsi. Banda Aceh: Universitas Syiah Kuala.

Sardiman (2015) Interaksi dan Motivasi Belajar Mengajar. Jakarta: Raja Grafindo Persada.

Siburian, F., Sinambela, M. and Septie, S. (2017). Analisis pelaksanaan praktikum pada mata pelajaran biologi di kelas x SMA Negeri 16 Medan. Jurnal Pelita Pendidikan, 5(2): 21-31.

Sudjana. (2005). Metode Statistik Edisi Ke-6. Bandung: Tarsito.

Sukmawati, M. (2013). Hambatan Pelaksanaan Praktikum Ipa Fisika Yang Dihadapi Guru SMP Negeri Di Kota Pekanbaru', Jurnal Pendidikan, 3(1): 1-11.

Tarmizi (2009) Majamenen Laboratorium. Padang: UNP Press.

Yaman, E. (2016). Pengoptimalan Peran Kepala Labor dalam Menunjang Pembelajaran IPA di SMPN 7 Kubung. JPGI (Jurnal Penelitian Guru Indonesia), 1(1): 63-71. 